\title{
In vivo evaluation of two tissue transglutaminase PET tracers in an orthotopic tumour xenograft model
}

\author{
Berend van der Wildt ${ }^{1} 2^{*}$ (D, Micha M. M. Wilhelmus ${ }^{2}$, Wissam Beaino ${ }^{1}$, Esther J. M. Kooijman ${ }^{1}$, Robert C. Schuit ${ }^{1}$, \\ John G. J. M. Bol ${ }^{2}$, John J. P. Breve², Ralf Pasternack ${ }^{3}$ Adriaan A. Lammertsma', Albert D. Windhorst ${ }^{1}$ \\ and Benjamin Drukarch ${ }^{2}$
}

\begin{abstract}
Background: The protein cross-linking enzyme tissue transglutaminase (TG2; EC 2.3.2.13) is associated with the pathogenesis of various diseases, including cancer. Recently, the synthesis and initial evaluation of two high-potential radiolabelled irreversible TG2 inhibitors were reported by us. In the present study, these two compounds were evaluated further in a breast cancer (MDA-MB-231) tumour xenograft model for imaging active tissue transglutaminase in vivo.

Results: The metabolic stability of $\left[{ }^{11} \mathrm{C}\right] 1$ and $\left[{ }^{18} \mathrm{~F}\right] 2$ in SCID mice was comparable to the previously reported stability in Wistar rats. Quantitative real-time polymerase chain reaction analysis on MDA-MB-231 cells and isolated tumours showed a high level of TG2 expression with very low expression of other transglutaminases. PET imaging showed low tumour uptake of $\left[{ }^{11} \mathrm{C}\right] 1$ (approx. 0.5 percentage of the injected dose per gram (\%/D/g) at 40-60 min p.i.) and with relatively fast washout. Tumour uptake for $\left[{ }^{18} \mathrm{~F}\right] 2$ was steadily increasing over time (approx. $1.7 \% \mathrm{ID} / \mathrm{g}$ at $40-60 \mathrm{~min}$ p.i.). Pretreatment of the animals with the TG2 inhibitor ERW1041E resulted in lower tumour activity concentrations, and this inhibitory effect was enhanced using unlabelled 2.
\end{abstract}

Conclusions: Whereas the TG2 targeting potential of $\left[{ }^{11} \mathrm{C}\right] 1$ in this model seems inadequate, targeting of TG2 using $\left[{ }^{18} \mathrm{~F}\right] 2$ was achieved. As such, $\left.{ }^{18} \mathrm{~F}\right] 2$ could be used in future studies to clarify the role of active tissue transglutaminase in disease.

Keywords: Transglutaminase type 2, Tissue transglutaminase, Positron emission tomography, MDA-MB-231

\section{Background}

Transglutaminases comprise a family of enzymes responsible for the calcium-dependent intra- and intermolecular cross-linking of proteins between the side chains of glutamine and lysine residues, forming an epsilon-(gamma-glutaminyl)-lysine bond [1]. Tissue transglutaminase (TG2) is ubiquitously expressed and, under physiological conditions, plays a role in, e.g. apoptosis, cell differentiation and cell migration $[2,3]$. The cross-linking activity of this enzyme is tightly regulated by various mechanisms. First, TG2 exists in two distinct conformations, referred to as closed and open conformations, respectively $[4,5]$. Only in the open

\footnotetext{
*Correspondence: bwildt@stanford.edu

${ }^{1}$ Department of Radiology \& Nuclear Medicine, VU University Medical Center, De Boelelaan 1085, 1081HV Amsterdam, The Netherlands

${ }^{2}$ Department of Anatomy \& Neurosciences, VU University Medical Center,

Amsterdam, The Netherlands

Full list of author information is available at the end of the article
}

conformation, which is associated with high-calcium and low-guanosine diphosphate/guanosine triphosphate (GDP/ GTP) concentrations, the active site cysteine residue is exposed and transamidation can be expected [5]. In the closed conformation, two consecutive C-terminal $\beta$-barrels sterically limit transamidation activity [4]. Second, the redox state of TG2 determines its catalytic activity, since a Cys370-Cys371 disulphide bridge, despite locking TG2 in its open conformation, hampers transamidation [6]. Finally, cross-linking activity of TG2 is regulated by formation of ternary protein complexes on the cell surface with extracellular matrix proteins, such as fibronectin and membranebound integrins [7]. Clearly, this multitude of regulatory mechanisms poses a challenge for assessing TG2 crosslinking activity in vivo. Often changes in TG2 expression levels or immunohistochemical detection of epsilon(gamma-glutaminyl)-lysine bonds are used as ex vivo 
biomarkers of TG2 activity. Alternatively, transglutaminase mediated incorporation of systemically administered biotin-labelled amine substrates can be detected immunohistochemically after sacrificing the test animal $[8,9]$.

TG2 is strongly associated with the pathogenesis of cancer, celiac disease, and fibrotic and neurodegenerative diseases [10-15], in which its role is assumed to be related to its cross-linking activity. The fact that TG2 knock-out mice are phenotypically healthy in a stressfree environment has further boosted TG2 as a potential target for therapeutic intervention [16]. Nowadays, a wide array of TG2 inhibitors has been developed [17]. Nevertheless, further development of potent inhibitors towards clinical studies, for example by evaluation in animal models, has been limited. The availability of a validated TG2 PET tracer is likely to stimulate in vivo research of potent TG2 inhibitors, because it will allow monitoring of target engagement in vivo by novel TG2 inhibitors [18]. As a result, a deeper understanding of TG2 biology in various diseases might be obtained.

Recently, carbon-11 and fluorine-18 labelled small molecule TG2 PET tracers have been developed by our group $[19,20]$. $\left[{ }^{11} \mathrm{C}\right] \mathbf{1}$ (Fig. 1, IC $5053 \mathrm{nM}$ ) was selected out of three carbon-11 labelled TG2 inhibitors based on its superior metabolic stability [19]. In addition, $\left[{ }^{18} \mathrm{~F}\right] 2$, a peptidic TG2 inhibitor (Fig. 1, $\mathrm{IC}_{50} 104 \mathrm{nM}$ ), was developed [20]. Despite being completely metabolised in vivo after just $15 \mathrm{~min}$ post injection, imaging with $\left[{ }^{18} \mathrm{~F}\right] 2$ was suggested as also the formed radiometabolite was previously shown to be an equipotent inhibitor of TG2 $\left(\mathrm{IC}_{50} 45 \mathrm{nM}\right)$ [20]. Both selected compounds, $\left[{ }^{11} \mathrm{C}\right] \mathbf{1}$ and $\left[{ }^{18} \mathrm{~F}\right] 2$, were able to discriminate between active and inactive tissue transglutaminase in vitro and demonstrated specific and selective binding to MDA-MB-231 tumour sections, as assessed by in vitro autoradiography experiments. However, in vitro autoradiography assays do not necessarily reflect in vivo biology. Therefore, the aim of the present study was to determine whether these new tracers are able to target TG2 also in vivo. To this end, compounds $\left[{ }^{18} \mathrm{~F}\right] \mathbf{1}$ and $\left[{ }^{18} \mathrm{~F}\right] \mathbf{2}$ were evaluated in a mouse MDA-MB-231 tumour xenograft model.

\section{Methods}

\section{Cell culture}

MDA-MB-231 human breast cancer cells were purchased from American Type Culture Collection (Rockville, MD, USA). Cells were cultured at $37{ }^{\circ} \mathrm{C}, 5 \% \mathrm{CO}_{2}$ in Dulbecco's modified Eagle medium with $4.5 \mathrm{~g} / \mathrm{L}$ glucose (Lonza, Basel, Switzerland) with HEPES supplemented with L-glutamine and fetal calf serum (5\%).

\section{Xenograft model}

Severe combined immunodeficient (SCID) female mice (6-8 weeks, 20 to $25 \mathrm{~g}$, Charles River, Wilmington, MA, USA) were housed in sterile cages under standard conditions $\left(24{ }^{\circ} \mathrm{C}, 60 \%\right.$ relative humidity, 12 -h light/dark cycles) and provided with water and food ad libitum. MDA-MB-231 cells $\left(1 \times 10^{6}\right)$ were injected orthotopically in the fat pad of the second thoracic mammary glands (bilateral) [21]. Tumour dimensions were measured using a Vernier calliper, and tumour volume was calculated using the formula $\left(x^{2} y\right) / 2(x$ and $y$ being the width and length, respectively) for an ellipsoid. At 8 weeks after MDA-MB-231 cell injection, tumours reached the target size of $200 \mathrm{~mm}^{3}$. This study was performed according to national regulations and was approved by the Animal Experimentation Ethics Committee of the VU University Medical Center.

\section{QPCR analysis}

Total messenger ribonucleic acid (mRNA) was isolated from MDA-MB-231 tumour cells or tumour tissue using Trizol Reagent (Invitrogen, Carlsbad, CA, USA) according to the manufacturer's instructions. RNA was reverse-transcribed into complementary deoxyribonucleic acid (cDNA) using the High-Capacity cDNA Reverse Transcription kit (Applied Biosystems, Foster City, Ca, USA) using $0.5 \mu$ g oligo-dT primers according to the manufacturer's instructions. For the subsequent quantitative real-time polymerase chain reaction (qPCR), the Power SYBR Green Master Mix (Applied Biosystems) was used. Primers were purchased from Eurogentec (Maastricht, Netherlands), and qPCR was performed in MicroAmp Optical 96-well Reaction Plates (Applied

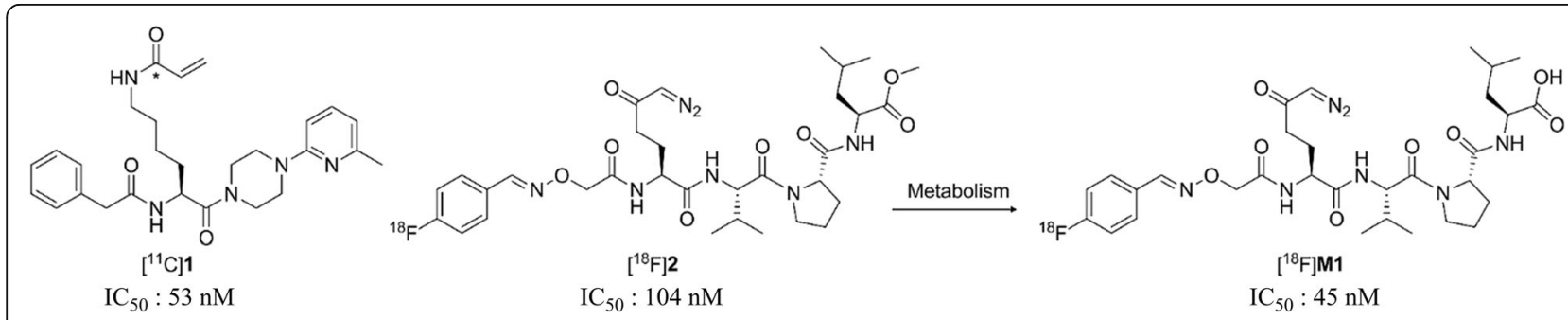

Fig. $\mathbf{1}$ Chemical structures and $I C_{50}$ values of the TG2 inhibitors $\left[{ }^{11} \mathrm{C}\right] \mathbf{1},\left[{ }^{18} \mathrm{~F}\right] \mathbf{2}$, together with that of its in vivo formed metabolite $\left[{ }^{18} \mathrm{~F}\right] \mathbf{M} \mathbf{1}[19,20]$. The position of the carbon-11 label in $\left[{ }^{11} \mathrm{C}\right] \mathbf{1}$ is depicted by an asterisk 
Biosystems) on a StepOnePlus Real-Time PCR system (Applied Biosystems). The reaction mixture $(20 \mu \mathrm{L})$ was composed of $1 \times$ Power SYBR Green buffer (Applied Biosystems), $3.75 \mathrm{pmol}$ of each primer (see Table 1 for primer details), and $12.5 \mathrm{ng}$ cDNA. The thermal cycling conditions were an initial $10 \mathrm{~min}$ at $95^{\circ} \mathrm{C}$ followed by 50 cycles of $15 \mathrm{~s}$ at $95{ }^{\circ} \mathrm{C}$ and $1 \mathrm{~min}$ at $60{ }^{\circ} \mathrm{C}$. The specificity of the reaction was checked by means of melt curve analysis. Relative expression levels of the target genes were determined by LinRegPCR software (version 2014.3; website: http://www.hfrc.nl) using the following equation $N_{0}=N_{\mathrm{q}}$ / $\left(E^{\wedge} C_{\mathrm{q}}\right)\left(N_{0}=\right.$ target quantity, $N_{\mathrm{q}}=$ fluorescence threshold value, $E=$ mean PCR efficiency per amplicon, $C_{\mathrm{q}}=$ threshold cycle) [22], after which the value was normalised to the expression level of the reference gene glyceraldehyde3-phosphate-dehydrogenase (GAPDH) using the following formula $\left(N_{\mathrm{o}}\right.$, gene of interest $\left./ \mathrm{N}_{\mathrm{o}}, \mathrm{GAPDH}\right)$. Results are expressed as gene expression relative to GAPDH \pm standard deviation ( $n=4$ for both tumour cells and tumour tissue measurements).

\section{Radiotracer synthesis}

(S)-N-(6-(4-(6-methylpyridin-2-yl)piperazin-1-yl)-6-oxo-5-(2phenylacetamido)hexyl) $\left[{ }^{11} \mathrm{C}\right.$ ]acrylamide $\left(\left[{ }^{11} \mathrm{C}\right] 1\right)$

$\left[{ }^{11} \mathrm{C}\right] \mathbf{1}$ was synthesised as previously described (Scheme 1) [19] and was obtained in 20-28\% decay corrected (d.c) yield based on $\left[{ }^{11} \mathrm{C}\right] \mathrm{CO}$ with a molar activity of $144 \pm$ $22 \mathrm{GBq} \cdot \mu \mathrm{mol}^{-1}$ and a radiochemical purity $>99 \%(n=4)$. The identity of the product was confirmed by analytical high-performance liquid chromatography (HPLC) analysis by co-injection of radiolabelled and unlabelled $\mathbf{1}$ using a Phenomenex Luna Phenyl-hexyl column $(5 \mu \mathrm{m}, 250 \mathrm{~mm} \times$ $4.6 \mathrm{~mm})$ with $\mathrm{H}_{2} \mathrm{O}$ /acetonitrile $(\mathrm{MeCN}), 7: 3(v / v)$ as eluent, with a flow rate of $1 \mathrm{~mL} / \mathrm{min}$, retention time $\left(R_{\mathrm{t}}\right) 9.0 \mathrm{~min}$.

(S)-methyl 2-((S)-1-((7S, 10S,E)-7-(4-diazo-3-oxobutyl)-1-(4$\left[^{18}\right.$ F]fluorophenyl)-10-isopropyl-5,8-dioxo-3-oxa-2,6,9triazaundec-1-en-11-oyl)pyrrolidine-2-carboxamido)-4methylpentanoate $\left.\left({ }^{18} \mathrm{~F}\right] 2\right)$

$\left[{ }^{18} \mathrm{~F}\right] 2$ was synthesised as previously described (Scheme 2) [20] and was obtained in 3-4\% d.c. yield, calculated at the time of the start of the synthesis, with a molar activity of $111 \pm 28 \mathrm{GBq} \cdot \mu \mathrm{mol}^{-1}$ and a radiochemical purity $>98 \%$ $(n=4)$. The identity of the product was confirmed by analytical HPLC analysis by co-injection of radiolabelled and unlabelled 2 using a Phenomenex Luna Phenyl-hexyl column $(5 \mu \mathrm{m}, 250 \mathrm{~mm} \times 4.6 \mathrm{~mm})$ with $\mathrm{H}_{2} \mathrm{O} / \mathrm{MeCN} / \mathrm{TFA}$, 60:40:0.1 $(v / v / v)$ as eluent, with a flow rate of $1 \mathrm{~mL} / \mathrm{min}, R_{\mathrm{t}}$ $28 \mathrm{~min}$.

\section{Metabolite analysis}

Healthy female SCID mice (20-25 g, Harlan, Horst, The Netherlands) were injected in the tail vein with $\left[{ }^{11} \mathrm{C}\right] \mathbf{1}$ or $\left[{ }^{18} \mathrm{~F}\right] 2(20 \mathrm{MBq})$ under isoflurane anaesthesia $\left(2 \%\right.$ in $\mathrm{O}_{2}$ at $\left.1 \mathrm{~L} \cdot \mathrm{min}^{-1}\right)$. Mice were sacrificed at 15 and $45 \mathrm{~min}$ post injection ( $n=3$ for each time-point) by cervical dislocation. Blood $(\sim 0.5-1 \mathrm{~mL})$ was withdrawn by heart puncture, collected in a heparin-coated tube and centrifuged at 5000 RPM to separate plasma from blood cells. Solid phase extraction (SPE) cartridges (tC18, Waters, Milford, MA, USA) were preconditioned by washing with methanol $\left(\mathrm{MeOH}, 6 \mathrm{~mL}\right.$ ) and $\mathrm{H}_{2} \mathrm{O}$ (two times $6 \mathrm{~mL})$. Plasma $(\sim 0.2 \mathrm{~mL})$ was mixed with $0.15 \mathrm{M} \mathrm{HCl}$ $(0.2 \mathrm{~mL})$ and loaded on the $\mathrm{tC} 18$ cartridge. The polar fraction was obtained by elution of the cartridge with $\mathrm{H}_{2} \mathrm{O}(3 \mathrm{~mL})$, the non-polar fraction by subsequent elution with $\mathrm{MeOH}(1.5 \mathrm{~mL})$ and $\mathrm{H}_{2} \mathrm{O}(0.5 \mathrm{~mL})$. Both fractions were counted for radioactivity in a gamma counter. The percentage of intact tracer in the nonpolar fraction was determined by online and offline HPLC analysis (Gemini C18 column $(5 \mu \mathrm{m}, 10 \mathrm{~mm} \times$ $250 \mathrm{~mm}$, Phenomenex, Torrance, CA, USA) with eluent $\mathrm{MeCN}$ (A) and $0.1 \%$ TFA acid in $\mathrm{H}_{2} \mathrm{O}$ (B) as eluent according to the following schemes; For $\left[{ }^{11} \mathrm{C}\right] \mathbf{1}$ : $0 \mathrm{~min}, 70 \% \mathrm{~B}$ at $0.25 \mathrm{~mL} \cdot \mathrm{min}^{-1} ; 0.5 \mathrm{~min}, 70 \% \mathrm{~B}$ at $3.5 \mathrm{~mL} \cdot \mathrm{min}^{-1} ; 9.0 \mathrm{~min}, 10 \% \mathrm{~B}$ at $3.5 \mathrm{~mL} \cdot \mathrm{min}^{-1}$; $12.0 \mathrm{~min}, 10 \% \mathrm{~B}$ at $3.5 \mathrm{~mL} \cdot \mathrm{min}^{-1} ; 12.5 \mathrm{~min}, 70 \% \mathrm{~B}$ at $3.5 \mathrm{~mL} \cdot \mathrm{min}^{-1} ; 14.5 \mathrm{~min}, 70 \% \mathrm{~B}$ at $3.5 \mathrm{~mL} \cdot \mathrm{min}^{-1}$ and $15 \mathrm{~min}, 70 \% \mathrm{~B}$ at $0.25 \mathrm{~mL} \cdot \mathrm{min}^{-1}$ or for $\left[{ }^{18} \mathrm{~F}\right] 2$ : $0 \mathrm{~min}, 80 \% \mathrm{~B}$ at $0.25 \mathrm{~mL} \cdot \mathrm{min}^{-1} ; 0.5 \mathrm{~min}, 80 \% \mathrm{~B}$ at $3 \mathrm{~mL} \cdot \min ^{-1} ; 6.0 \mathrm{~min}, 30 \% \mathrm{~B}$ at $3 \mathrm{~mL} \cdot \min ^{-1} ; 12.0 \mathrm{~min}$, $30 \% \mathrm{~B}$ at $3 \mathrm{~mL} \cdot \mathrm{min}^{-1} ; 12.5 \mathrm{~min}, 80 \% \mathrm{~B}$ at $3.0 \mathrm{~mL} \cdot \mathrm{min}^{-1}$; $14.5 \mathrm{~min}, 80 \% \mathrm{~B}$ at $3.0 \mathrm{~mL} \cdot \mathrm{min}^{-1} ; 15.0 \mathrm{~min}, 80 \% \mathrm{~B}$ at $0.25 \mathrm{~mL} \cdot \min ^{-1}\left(R_{\mathrm{t}}=11.5 \mathrm{~min}\right)$. Offline HPLC analysis was performed when the online HPLC analysis yielded a low signal to noise ratio. For offline analysis, HPLC fractions (30 s per fraction) were collected and counted for radioactivity (WIZARD

Table 1 Primer sequences used for qPCR analysis

\begin{tabular}{lllll}
\hline Gene & NCBI reference sequence & Forward $\left(5^{\prime} \rightarrow 3^{\prime}\right)$ & Reverse $\left(3^{\prime} \rightarrow 5^{\prime}\right)$ & Amplicon size $($ base pairs) \\
\hline GAPDH & NM_002046.3 & TCAAGGGCATCCTGGGCTAC & CGTCAAAGGTGGAGGAGTGG & 81 \\
TGM1 & NM_000359.2 & CAATGTCTCAGGCCACGTC & CCAGTAACGTGAGGGAGAGG & 95 \\
TGM2 & NM_004613.2 & AGAGGAGCGGCAGGAGTATG & AGGATCCCATCTTCAAACTGC & 111 \\
TGM3 & NM_003245.3 & AACCTGAAGATCGACGTGC & CAGTTGCTTGGTGCCACTC & 93 \\
TGM5 & NM_201631.3 & TCCTGGTGAACAAGATCATC & GTATGGAGAGTGGCTGGTC & 90 \\
F13A1 & NM_000129.3 & TCCGCAGAGGGCAGTCTTC & CCTGTGGGTAGCGACCAATGA & 105 \\
\hline
\end{tabular}




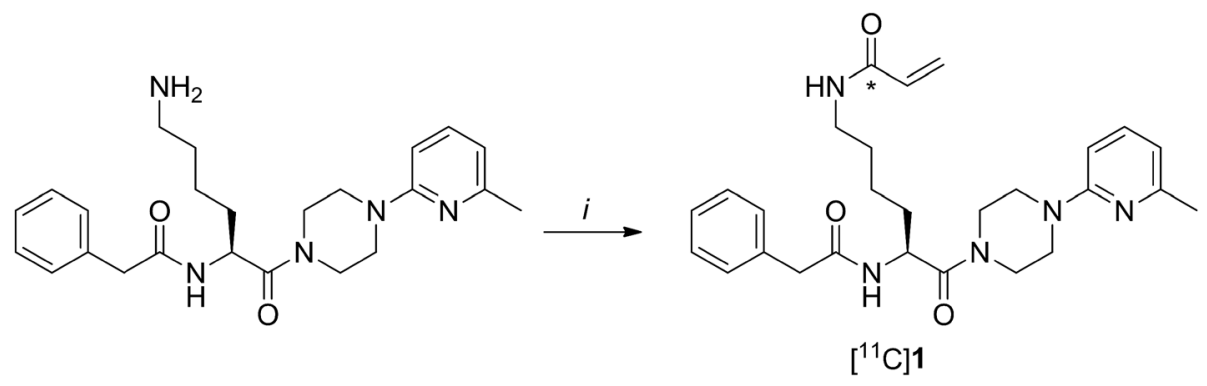

Scheme 1 Radiosynthesis of $\left[{ }^{11} \mathrm{C}\right] \mathbf{1}$. Reagents and conditions: (i) $\left[{ }^{11} \mathrm{C}\right] \mathrm{CO}$, vinyl iodide, $\mathrm{Pd} \mathrm{d}_{2}(\mathrm{dba})_{3}, \mathrm{PPh}_{3}$, tetrahydrofuran $(\mathrm{THF}), 5 \mathrm{~min}, 100{ }^{\circ} \mathrm{C}$

2480 Compugamma, PerkinElmer, Waltham, MA, USA). The counting results were plotted to generate the corresponding HPLC chromatograms. Data were expressed as percentage of intact tracer, polar metabolites, and non-polar metabolites \pm standard deviation.

\section{Metabolite characterisation}

To healthy SCID mice $(n=2) 10 \mathrm{MBq}\left[{ }^{18} \mathrm{~F}\right] 2$ diluted with $50 \mu \mathrm{g}\left(2.5 \mathrm{mg} \cdot \mathrm{kg}^{-1}\right)$ of unlabelled 2 was administered, corresponding to a molar activity of $0.14 \mathrm{GBq} \cdot \mu \mathrm{mol}^{-1}$. At 30 min post injection, animals were sacrificed under isoflurane anaesthesia $\left(2 \%\right.$ in $\mathrm{O}_{2}$ at $\left.1 \mathrm{~L} \cdot \mathrm{min}^{-1}\right)$ by cervical dislocation. Blood $(\sim 1 \mathrm{~mL})$ was collected by heart puncture. Blood plasma was separated using a SPE procedure as described in the "Metabolite analysis" section (vide supra). The non-polar fraction was analysed by HPLC and Liquid chromatography-tandem mass spectrometry (LC-MS/MS) in multiple reaction monitoring (MRM) mode. LC-MS/MS analysis was performed on a Jasco system (Easton, PA, USA) with an AB Sciex QTRAP 5500 mass spectrometer
(Concorde, Ontario, Canada). The Jasco system consisted of two pumps (X-LC 3180PU), a degasser (X-LC 3080DG), a mixer (X-LC 3080MX), a column oven (X-LC 3080CO), and databoxes LV 2080-03 and LC-Net II/ACD. A Kinetex C18 column $(1.7 \mathrm{u}, 100 \mathrm{~A}, 100 \times 2.10 \mathrm{~mm}$, Phenomenex, Torrance, CA, USA) at $25^{\circ} \mathrm{C}$ was used for chromatographic separation with eluent $\mathrm{MeCN}(\mathrm{A})$ and $0.1 \%$ formic acid in $\mathrm{H}_{2} \mathrm{O}$ (B) according to the following scheme: $0 \mathrm{~min}, 90 \% \mathrm{~B}$ at $0.5 \mathrm{~mL} \cdot \mathrm{min}^{-1}$; $3 \mathrm{~min}, 10 \% \mathrm{~B}$ at $0.5 \mathrm{~mL} \cdot \mathrm{min}^{-1} ; 5 \mathrm{~min}, 10 \%$ $\mathrm{B}$ at $0.5 \mathrm{~mL} \cdot \min ^{-1} ; 5.5 \mathrm{~min} 90 \% \mathrm{~B}$ at $0.5 \mathrm{~mL} \cdot \mathrm{min}^{-1}$. Capillary potential was set at $5.5 \mathrm{kV}$, source temperature at $100{ }^{\circ} \mathrm{C}$, and desolvation temperature at $750{ }^{\circ} \mathrm{C}$. MRM Q1 and Q3 set at $696.2-418.0 \mathrm{~m} / \mathrm{z}$ for detection of compound 2 and $682.1-626.3 \mathrm{~m} / \mathrm{z}$ for detection of M1.

\section{Chemical synthesis \\ General}

All reagents were obtained from commercial sources (Sigma Aldrich, St. Louis, USA). Solvents were obtained from Biosolve (Valkenswaard, the Netherlands) and used

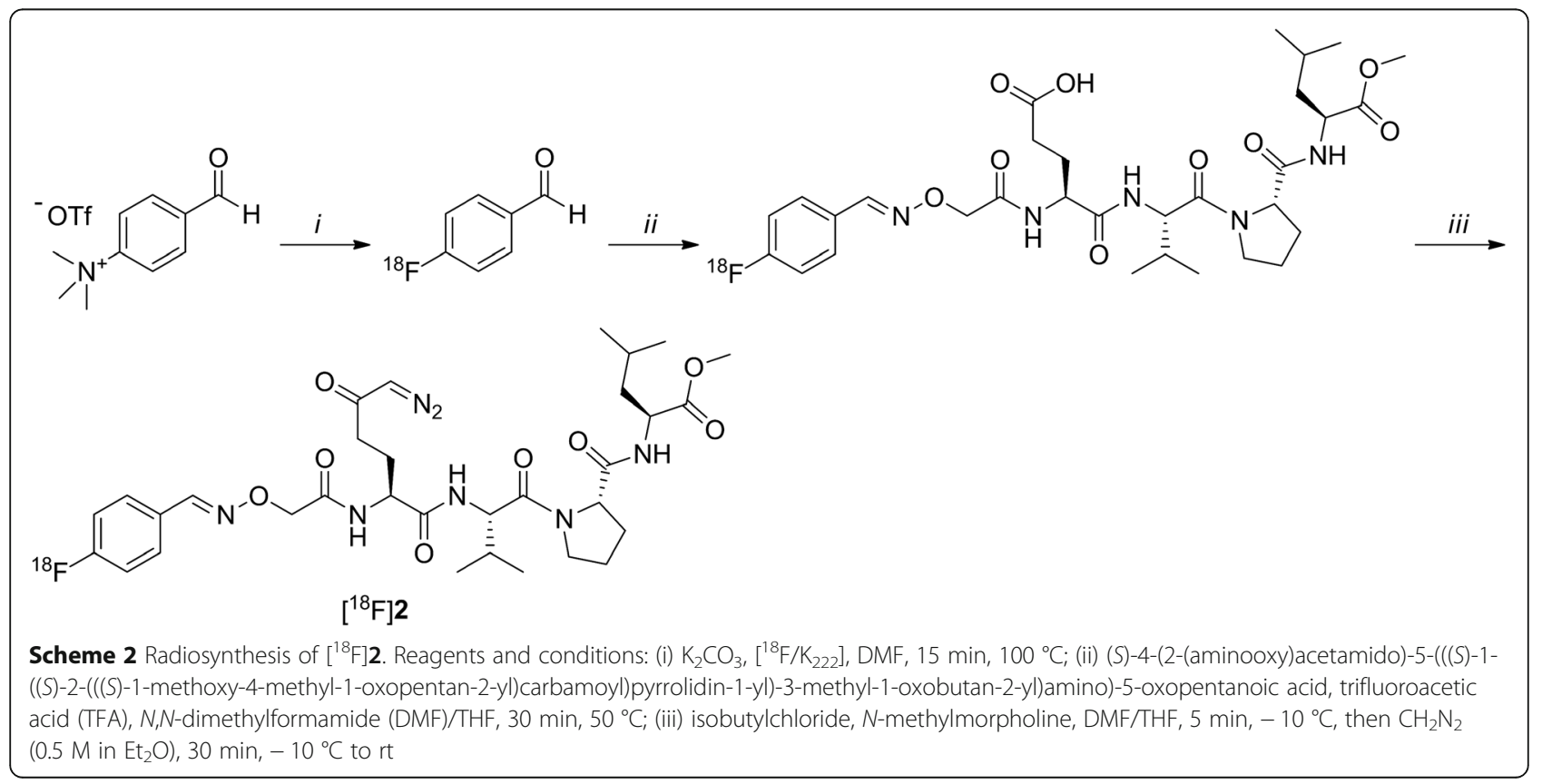


as received unless stated otherwise. Dichloromethane (DCM) and DMF were dried over activated $3 \AA$ molecular sieves. THF was first distilled from $\mathrm{LiAlH}_{4}$ and then stored on activated $3 \AA$ molecular sieves. Reaction monitoring by thin-layer chromatography was performed on precoated silica 60 F254 aluminium plates (Merck, Darmstadt, Germany). Spots were visualised by UV light or ninhydrin. Evaporation of solvents was performed under reduced pressure at $40{ }^{\circ} \mathrm{C}$ using a rotary evaporator. Flash column chromatography was performed manually on Silica gel $60 \AA$ (Merck, Darmstadt, Germany). Nuclear magnetic resonance (NMR) spectroscopy was performed using a Bruker (Billerica, MA, USA) Avance 250 (250.13 MHz for ${ }^{1} \mathrm{H}$ and 62. $90 \mathrm{MHz}$ for ${ }^{13} \mathrm{C}$ ) or an Avance $500\left(500.23 \mathrm{MHz}\right.$ for ${ }^{1} \mathrm{H}$ and $125.78 \mathrm{MHz}$ for ${ }^{13} \mathrm{C}$ ) with chemical shifts $(\delta)$ reported in parts per million (ppm) relative to the solvent (chloroform $\left.\left(\mathrm{CDCl}_{3}\right),{ }^{1} \mathrm{H} \quad 7.26 \mathrm{ppm},{ }^{13} \mathrm{C} \quad 77.16 \mathrm{ppm}\right)$. Electrospray ionisation-high resolution mass spectrometry (ESI-HRMS) was carried out using a Bruker microTOF-Q instrument in positive ion mode (capillary potential of $4500 \mathrm{~V}$ ).

(S)-methyl 2-((S)-1-((7S, 10S)-7-(4-diazo-3-oxobutyl)-1-(4fluorophenyl)-10-isopropyl-5,8-dioxo-3-oxa-2,6,9triazaundec-1-en-11-oyl)pyrrolidine-2-carboxamido)-4methylpentanoate (2)

The synthesis of unlabelled 2 was performed as published elsewhere [20].

Synthesis of ERW1041E was performed according to published procedures (Scheme 3) [9]. Analytical characterizations were in accordance with reported values $[9,23]$.

\section{(S)-(3-Bromo-4,5-dihydroisoxazol-5-yl)methanamine (4)}

A solution of $50 \%$ glyoxylic acid $(15.0 \mathrm{~mL}, 135 \mathrm{mmol})$ and hydroxylamine hydrochloride $(9.40 \mathrm{~g}, 135 \mathrm{mmol})$ in $\mathrm{H}_{2} \mathrm{O}(50 \mathrm{~mL})$ was stirred for $2 \mathrm{~h}$ at room temperature (rt). Sodium bicarbonate was added (22.7 g, $270 \mathrm{mmol})$, and the resulting solution was cooled on ice. Bromine was added dropwise $(9.00 \mathrm{~mL}, 176 \mathrm{mmol})$, and the resulting solution was stirred overnight at rt. The mixture was extracted with DCM (three times $100 \mathrm{~mL}$ ). The combined organic fractions were dried on $\mathrm{Na}_{2} \mathrm{SO}_{4}$, filtered and carefully concentrated in vacuo to afford dibromoformaldoxime 3 as a white solid (14.1 g, 52\%), which was immediately used as such in the subsequent reaction. To a solution of allylamine hydrochloride $(7.0 \mathrm{~g}$, $75 \mathrm{mmol})$ in $\mathrm{H}_{2} \mathrm{O}(100 \mathrm{~mL})$ was added dibromoformaldoxime 3 (10 g, $49 \mathrm{mmol}$ ). To this solution was added dropwise a solution of $\mathrm{KHCO}_{3}(6.0 \mathrm{~g}, 60 \mathrm{mmol})$ in $\mathrm{H}_{2} \mathrm{O}$ $(50 \mathrm{~mL})$ over a 3 -h period while stirring vigorously at $\mathrm{rt}$. The resulting solution was stirred for another $3 \mathrm{~h}$ prior to dilution with saturated $\mathrm{NaHCO}_{3}(100 \mathrm{~mL})$. After extraction with DCM (three times $100 \mathrm{~mL}$ ), the combined organic fractions were dried on $\mathrm{Na}_{2} \mathrm{SO}_{4}$ and concentrated in vacuo. Flash column chromatography (DCM/MeOH, 9:1 $(v / v)$ ) afforded racemic (3-bromo-4,5-dihydroisoxazol-5yl) methanamine as a yellow oil (5.1 g, 58\%). Enantiomeric enrichment was performed as follows: to a solution of racemic (3-bromo-4,5-dihydroisoxazol-5-yl) methanamine $(2.3 \mathrm{~g}, 12.9 \mathrm{mmol})$ and L-mandelic acid $(1.0 \mathrm{~g}, 6.4 \mathrm{mmol})$ in hot $\mathrm{MeOH}$ was added dropwise hot isopropanol. The solution was allowed to cool to rt and left for $16 \mathrm{~h}$. The solids were filtered off and recrystallization was performed

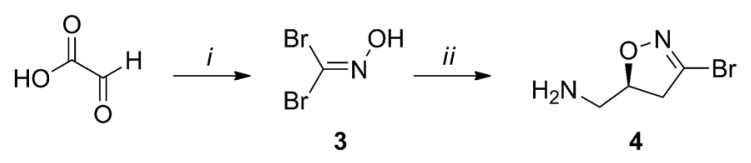<smiles>CC#CC=Cc1cnc2ccccc2c1</smiles><smiles>CCOC(=O)c1cccc2ncc(COC(=O)N3CCC[C@H]3C(=O)NCC3CC(Br)=NO3)cc12</smiles>

Scheme 3 Synthesis of ERW1041E. Reagents and conditions: (i) hydroxylamine hydrochloride, $\mathrm{H}_{2} \mathrm{O}, 2 \mathrm{~h}$, room temperature (rt), then $\mathrm{NaHCO}_{3}, \mathrm{Br}_{2}$ $16 \mathrm{~h}, 0{ }^{\circ} \mathrm{C}$ to rt, 52\%; (ii) allylamine hydrochloride, $\mathrm{KHCO}_{3}, \mathrm{H}_{2} \mathrm{O}, 3 \mathrm{~h}$, rt, 50\%; (iii) $\mathrm{LiBH}_{4}$, ethanol/THF, $2 \mathrm{~h},-80{ }^{\circ} \mathrm{C}$, then CDI, MeCN, $2 \mathrm{~h}$, rt, $78 \%$; (iv) proline methyl ester hydrochloride, DiPEA, DCM/DMF, 16 h, rt, 60\%; (v) NaOH, dioxane/MeOH/H $/ \mathrm{H}_{2} \mathrm{O} 2 \mathrm{~h}$, rt, 89\%; (vi) amine 4, EDC, HOBt, $\mathrm{N}$-methylmorpholine, DMF, 2 h, rt, 96\% 
out of a hot $\mathrm{MeOH}$ /isopropanol mixture until white crystalline needles were formed. After filtration, the needles were dissolved in saturated $\mathrm{NaHCO}_{3}$ and the solution was extracted with DCM (three times $20 \mathrm{~mL}$ ). After drying on $\mathrm{Na}_{2} \mathrm{SO}_{4}$, filtration and concentration in vacuo, product 4 was obtained as a colourless oil $1.0 \mathrm{~g}, 87 \%) .{ }^{1} \mathrm{H}$ NMR (500 MHz, $\left.\mathrm{CDCl}_{3}\right): \delta 4.74(\mathrm{~m}, 1 \mathrm{H}), 3.25(\mathrm{dd}, 1 \mathrm{H}, J=17.4$, $10.7 \mathrm{~Hz}$ ), 3.08 (dd, 1H, $J=17.0,7.8 \mathrm{~Hz}), 3.01(\mathrm{dd}, 1 \mathrm{H}$, $J=13.5,3.8 \mathrm{~Hz})$ and $2.58(\mathrm{dd}, 1 \mathrm{H}, J=13.5,5.7 \mathrm{~Hz}) ;{ }^{13} \mathrm{C}$ NMR (125 MHz, $\mathrm{CDCl}_{3}$ ): $\delta$ 137.52, 83.11, 44.99 and 43.85; ESI-HRMS calculated for $\mathrm{C}_{4} \mathrm{H}_{7} \mathrm{BrN}_{2} \mathrm{O}$ : 177.9742, found: $178.9811[\mathrm{M}+\mathrm{H}]^{+}$.

\section{Quinolin-3-ylmethyl 1H-imidazole-1-carboxylate (5)}

A solution of quinolone-3-carbaldehyde (2.50 g, $15.9 \mathrm{mmol})$ in ethanol/THF $(20 \mathrm{~mL})$ was cooled to $-80{ }^{\circ} \mathrm{C}$ prior to the addition of $\mathrm{LiBH}_{4}(0.34 \mathrm{~g}, 16 \mathrm{mmol})$. After stirring for $2 \mathrm{~h}$, the mixture was quenched with $1 \mathrm{M} \mathrm{HCl}(100 \mathrm{~mL})$ and allowed to reach $\mathrm{rt}$. The resulting solution was diluted with saturated $\mathrm{NaHCO}_{3}(100 \mathrm{~mL})$ and extracted ethyl acetate (EtOAc) (three times $50 \mathrm{~mL}$ ). The collected EtOAc fractions were dried on $\mathrm{Na}_{2} \mathrm{SO}_{4}$, filtered and concentrated in vacuo to obtain quinolyn-3-ylmethanol as yellow oil. Quinolyn-3-ylmethanol (2.40 g, $15.1 \mathrm{mmol})$ was dissolved in $\mathrm{MeCN}(10 \mathrm{~mL})$ and carbonyldiimidazole (4.90 g, 30. $2 \mathrm{mmol}$ ) was added to this solution. After stirring for $2 \mathrm{~h}$ at rt, the white precipitate was filtered and carefully washed with ice-cold acetonitrile $(10 \mathrm{~mL})$ obtaining compound 5 as a white solid (2.98 g, 78\%). ${ }^{1} \mathrm{H}$ NMR $\left(250 \mathrm{MHz}, \mathrm{CDCl}_{3}\right)$ : $\delta 9.01(\mathrm{~d}, 1 \mathrm{H}, J=2.2 \mathrm{~Hz}), 8.27(\mathrm{~d}, 1 \mathrm{H}, J=2.1 \mathrm{~Hz}), 8$. 17-8.13 (m, 2H), $7.88(\mathrm{dd}, 1 \mathrm{H}, J=8.1,1.2 \mathrm{~Hz}), 7.79$ (m, 1H), $7.61(\mathrm{~m}, 1 \mathrm{H}), 7.44(\mathrm{~m}, 1 \mathrm{H}), 7.07(\mathrm{dd}, 1 \mathrm{H}, J=1.8$, $0.9 \mathrm{~Hz})$ and $5.62(\mathrm{~s}, 2 \mathrm{H}) ;{ }^{13} \mathrm{C} \mathrm{NMR}\left(125 \mathrm{MHz} \mathrm{CDCl}_{3}\right)$ : $\delta 150.72,148.65,148.41,137.25,136.89,131.01,130.63$, $129.53,128.14,127.55,127.53,126.87,117.24$ and 67.61 .

\section{2-Methyl 1-(quinolin-3-ylmethyl) (S)-pyrrolidine-1,2- dicarboxylate (6)}

To a solution of L-proline methyl ester hydrochloride (1. $3 \mathrm{~g}, 7.9 \mathrm{mmol})$ and DiPEA (1.4 mL, $7.9 \mathrm{mmol})$ in DCM/ DMF $(1: 1(v / v), 10 \mathrm{~mL})$ was added compound 5 (2.0 g, $7.9 \mathrm{mmol})$ in DCM $(5 \mathrm{~mL})$ and the solution was stirred at rt. for $16 \mathrm{~h}$. After concentrating in vacuo, the residue was dissolved in EtOAc and purified by flash column chromatography (hexane/EtOAc 3:2) obtaining compound 6 as a colourless oil (1.50 g, 60\%). ${ }^{1} \mathrm{H}$ NMR (250 MHz, $\mathrm{CDCl}_{3}$, mixture of rotamers): $\delta 8.93$ and 8.87 $(2 \times \mathrm{d}, 1 \mathrm{H}, J=2.2 \mathrm{~Hz}), 8.11(\mathrm{dt}, 1 \mathrm{H}, J=12.1,1.4 \mathrm{~Hz}), 7$. 84-7.79 (m, 1H), 7.75-7.66 (m, 1H), 7.58-7.51 (m, 1H), 5.41-5.20 (m, 2H), 4.37 (dt, $1 \mathrm{H}, J=8.9,3.8 \mathrm{~Hz}), 3.73-3$. $45(\mathrm{~m}, 5 \mathrm{H})$ and $2.27-1.85(\mathrm{~m}, 5 \mathrm{H}) ;{ }^{13} \mathrm{C} \mathrm{NMR}(500 \mathrm{MHz}$, $\mathrm{CDCl}_{3}$, mixture of rotamers): $\delta 173.21,173.05,154.66$, $154.04,150.82,150.61,147.92,147.88,135.53,135.26$, $129.77,129.74,129.73,129.52,129.48,129.35,128.00$,
127.96, 127.73, 127.00, 64.89, 64.78, 59.31, 58.92, 52.40, 52.32, 47.10, 46.57, 31.01, 29.96, 24.40 and 23.57; ESIHRMS: calculated for $\mathrm{C}_{17} \mathrm{H}_{18} \mathrm{~N}_{2} \mathrm{O}_{4}:$ 314.1267, found: 315.1348; $337.1158[\mathrm{M}+\mathrm{H}]^{+},[\mathrm{M}+\mathrm{Na}]^{+}$.

\section{((Quinolin-3-ylmethoxy)carbonyl)-L-proline (7)}

A solution of compound 6 (1.00 g, $3.18 \mathrm{mmol})$ in Tesser's base (dioxane/MeOH/4 M NaOH, 6:4:2 (v/v/v) $10 \mathrm{~mL}$ ) was stirred for $2 \mathrm{~h}$ at $\mathrm{rt}$ prior to acidification to $\mathrm{pH} 4$ with $1 \mathrm{M} \mathrm{HCl}$. The solution was extracted with DCM (six times $20 \mathrm{~mL}$ ). The combined organic fractions were dried on $\mathrm{Na}_{2} \mathrm{SO}_{4}$, filtered and concentrated in vacuo, obtaining compound 7 as a white solid (0.85 g, 89\%). ${ }^{1} \mathrm{H}$ NMR (500 $\mathrm{MHz}, \mathrm{CDCl}_{3}$, mixture of rotamers): $\delta 11.32$ (br s, $1 \mathrm{H}), 8.93$ (s, 1H), 8.27 (s, 1H), 7.83-7.67 (m, 2H), 7.56-7. $41(\mathrm{~m}, 2 \mathrm{H}), 5.56(\mathrm{~d}, 1 \mathrm{H}, J=13 \mathrm{~Hz}), 5.09(\mathrm{~d}, 1 \mathrm{H}, J=12$. $6 \mathrm{~Hz}), 4.47-4.38(\mathrm{~m}, 1 \mathrm{H}), 3.68-3.61(\mathrm{~m}, 1 \mathrm{H}), 3.56-3.47$ (m, 1H), 2.32-2.10 (m, 2H) and $2.01-1.85(\mathrm{~m}, 2 \mathrm{H}) ;{ }^{13} \mathrm{C}$ NMR (500 MHz, $\mathrm{CDCl}_{3}$, mixture of rotamers): $\delta 175.58$, 175.25, 154.97, 154.21, 149.16, 148.74, 144.34, 138.05, 137. $38,130.75,130.70,130.04,128.07,127.98,127.89,127.70$, 127.61, 127.32, 125.98, 64.53, 64.19, 59.78, 59.45, 47.18, 46.72, 31.03, 29.88, 24.40 and 23.71; ESI-HRMS: calculated for $\mathrm{C}_{16} \mathrm{H}_{16} \mathrm{~N}_{2} \mathrm{O}_{4}$ : 300.1110, found: 301.1189; 323 . $1006[\mathrm{M}+\mathrm{H}]^{+},[\mathrm{M}+\mathrm{Na}]^{+}$.

\section{Quinolin-3-ylmethyl (S)-2-((((S)-3-bromo-4,5- dihydroisoxazol-5-yl)methyl)carbamoyl)pyrrolidine-1- carboxylate (ERW1041E)}

A solution of carboxylic acid $7(0.40 \mathrm{~g}, 1.3 \mathrm{mmol})$, amine 4 (0.24 g, $1.3 \mathrm{mmol})$, 1-ethyl-3-(3-dimethylaminopropyl) carbodiimide (EDC, $0.28 \mathrm{~g}, 1.5 \mathrm{mmol}$ ), hydroxybenzotriazole (HOBt, $0.20 \mathrm{mg}, 1.3 \mathrm{mmol}$ ) and $N$-methylmorpholine $(0.15 \mathrm{~mL}, 1.3 \mathrm{mmol})$ in DMF $(5 \mathrm{~mL})$ was stirred for $2 \mathrm{~h}$. The solution was concentrated in vacuo, and the residue was purified by flash column chromatography (DCM/MeOH, 25:1 $(v / v)$ ), obtaining the product as colourless solid (0.59 g, 96\%). ${ }^{1} \mathrm{H}$ NMR (500 MHz, $\mathrm{CDCl}_{3}$, mixture of rotamers): $\delta 8.85(\mathrm{~m}, 1 \mathrm{H}), 8.09(\mathrm{~m}$, $2 \mathrm{H}), 7.78(\mathrm{~m}, 1 \mathrm{H}), 7.67(\mathrm{~m}, 1 \mathrm{H}), 7.52(\mathrm{~m}, 1 \mathrm{H}), 7.07-6.91$ (m, 1H), 5.35-5.21 (m, 2H), 4.75-4.54 (m, 1H), $4.29(\mathrm{~m}$, $1 \mathrm{H}), 3.65-3.35(\mathrm{~m}, 4 \mathrm{H}), 3.18-2.80(\mathrm{~m}, 2 \mathrm{H})$ and $2.12-$ $1.83(\mathrm{~m}, 4 \mathrm{H}) ;{ }^{13} \mathrm{C} \mathrm{NMR}\left(125 \mathrm{MHz} \mathrm{CDCl}_{3}\right.$, mixture of rotamers): $\delta 173.19,172.72,155.32,154.49,150.63$, 147.72 , 138.00, 137.44, 135.56, 129.77, 129.22, 129.10, $127.91,127.55,126.94,80.49,80.21,65.07,64.89,60.86$, 60.63, 47.55, 47.05, 43.80, 43.62, 41.78, 41.23, 31.47, 29.59, 24.51 and 23.59; ESI-HRMS: calculated for $\mathrm{C}_{20} \mathrm{H}_{21} \mathrm{BrN}_{4} \mathrm{O}_{4}$ : 460.0746, found: 461.0805, 483.0620 $[\mathrm{M}+\mathrm{H}]^{+},[\mathrm{M}+\mathrm{Na}]^{+}$.

\section{PET imaging}

Dynamic PET imaging was performed using dedicated small animal NanoPET/CT and NanoPET/MR scanners 
(Mediso Ltd., Hungary, Budapest) [24, 25] with identical PET components. Mice ( $n=4$ per group) were anaesthetized with 4 and $2 \%$ isoflurane in $1 \mathrm{~L} \cdot \mathrm{min}^{-1}$ oxygen for induction and maintenance, respectively. Mice were positioned on the scanner bed, and the respiratory rate was monitored for the duration of the scan, adjusting anaesthesia when required. A dynamic PET scan was acquired immediately after intravenous (i.v.) administration (tail vein) of $5 \mathrm{MBq}\left[{ }^{11} \mathrm{C}\right] \mathbf{1}$ or $\left[{ }^{18} \mathrm{~F}\right] 2$. For blocking experiments, mice were injected subcutaneously with ERW1041E (50 mg $\cdot \mathrm{kg}^{-1}$ ) dissolved in $20 \%$ dimethylsulfoxide in $0.9 \%$ saline, $30 \mathrm{~min}$ prior to the tracer injection. An additional blocking experiment was performed by co-administration of compound $2(50 \mu \mathrm{g}$, $75 \mathrm{nmol}$ ) and $\left[{ }^{18} \mathrm{~F}\right] 2$, which corresponded with a molar activity of $0.07 \mathrm{GBq} \cdot \mu \mathrm{mol}^{-1}$. PET scans were acquired in list mode and rebinned into the following frame sequence: $4 \times 5,4 \times 10,2 \times 30,3 \times 60,2 \times 300,1 \times 600,1 \times 900$ and $1 \times 1200 \mathrm{~s}$. In addition, a static $\left[{ }^{18} \mathrm{~F}\right] 2$-fluoro-2-deoxy-Dglucose $\left(\left[{ }^{18} \mathrm{~F}\right] \mathrm{FDG}\right)$ scan was acquired for $30 \mathrm{~min}$ immediately after $\left[{ }^{18} \mathrm{~F}\right] \mathrm{FDG}$ administration $(10 \mathrm{MBq}$, tail vein). At least a 24-h time interval between $\left[{ }^{18} \mathrm{~F}\right] \mathrm{FDG}$ scans and $\left[{ }^{11} \mathrm{C}\right] \mathbf{1}$ or $\left[{ }^{18} \mathrm{~F}\right] \mathbf{2}$ scans was maintained. Reconstruction was performed with a fully 3-dimensional (3D) reconstruction algorithm using four iterations and six subsets, resulting in an isotropic $0.4-\mathrm{mm}$ voxel dimension. Images were analysed using the freely available AMIDE-software version 1.0.4 (retrieved from https:// sourceforge.net/projects/amide/files/amide/1.0.4). Regions of interest (ROIs) were drawn around the tumour tissue and leg muscle. Results are expressed as percentage injected dose per gram (\%ID/g). Error bars indicate standard deviation. After PET scanning experiments, animals were sacrificed by cervical dislocation, tumours were isolated, and stored at $-80{ }^{\circ} \mathrm{C}$ until further use.

\section{Haematoxylin and eosin staining}

MDA-MB-231 tumour sections $(10 \mu \mathrm{m})$ were dried and fixed with acetone (100\%) for $10 \mathrm{~min}$ and subsequently dried at rt. Sections were then rehydrated in Tris buffered saline (TBS; two times $5 \mathrm{~min}$ ) and demiwater (5 min) and stained with Mayer's haematoxylin solution (3 $\mathrm{min}$ ) followed by rinsing with tap water $(5 \mathrm{~min})$. The sections were stained with $1 \%$ eosin Y solution (10-30 s) followed by dehydrating by sequential dipping in ethanol (70, 90, 96, 100 and 100\%) and xylene. Sections were then mounted with coverslips using Entellan. Microscopy images were obtained using a Leica DN5000B microscope (Leica Microsystems, IL, USA).

\section{Immunohistochemical staining}

Immunohistochemical staining of TG2 was performed as described previously with minor modifications [19]. Fresh frozen MDA-MB-231 tumour sections $(10 \mu \mathrm{m})$ were dried and fixed with acetone (100\%) for $10 \mathrm{~min}$, dried at rt and subsequently rehydrated using TBS (three times $5 \mathrm{~min}$ ). Endogenous peroxidase activity was blocked with $0.3 \% \mathrm{H}_{2} \mathrm{O}_{2}$ and $0.1 \% \mathrm{NaN}_{3}$ in TBS for $15 \mathrm{~min}$ and then washed with TBS (three times $5 \mathrm{~min}$ ). After blocking with $3 \%$ bovine serum albumin (BSA) in TBS with $0.5 \%$ TritonX-100 (TBS-T) for $20 \mathrm{~min}$, incubation with polyclonal goat anti-guinea pig TG2 antibody (Upstate, Merck Millipore, Billerica, MA, USA) in TBS-T with 3\% BSA was performed overnight at $4{ }^{\circ} \mathrm{C}$ (dilution 1:4000). A negative control experiment was performed by omitting the primary antibody (results not shown). Sections were then washed with TBS (three times $5 \mathrm{~min}$ ) prior to incubation with biotinylated donkey anti-goat secondary antibody (Jackson ImmunoResearch Laboratories Inc., West Grove, PA, USA, dilution 1:400) for $2 \mathrm{~h}$ at rt. Excess antibody was removed by washing with TBS (three times $5 \mathrm{~min}$ ), and sections were incubated for $1 \mathrm{~h}$ with horseradish peroxidase avidin-biotin complex. After sequential washing with TBS (two times $5 \mathrm{~min}$ ) and Tris- $\mathrm{HCl}(5 \mathrm{~min})$, peroxidasemediated [1,1' -biphenyl]-3,3',4,4' -tetraamine (DAB) oxidation was used for visualising TG2. Colouring was monitored ad oculos. After colouring was satisfactory, sections were washed sequentially with Tris- $\mathrm{HCl}$ (two times $5 \mathrm{~min}$ ) and water (5 min). Dehydration was carried out by sequential dipping in ethanol (70, 90, 96, 100 and 100\%) and xylene, and sections were mounted with coverslips using Entellan. Microscopy images were obtained using a Leica DN5000B microscope (Leica Microsystems, IL, USA).

\section{Histochemical staining}

Histochemical staining of active TG2 was performed as described previously [19]. MDA-MB-231 tumour sections $(10 \mu \mathrm{m})$ were pre-incubated in $100 \mathrm{mM}$ Tris- $\mathrm{HCl}$ buffer ( $\mathrm{pH}$ 7.4), $5 \mathrm{mM} \mathrm{CaCl}, 1 \mathrm{mM}$ dithiothreitol (DTT) rt $(20 \mathrm{~min})$. As negative control, the selective TG2 inhibitor Z006 was added to this solution at a final concentration of $100 \mu \mathrm{M}$ (results not shown). Next, sections were incubated in $100 \mathrm{mM}$ Tris- $\mathrm{HCl}$ buffer ( $\mathrm{pH}$ 7.4), $5 \mathrm{mM} \mathrm{CaCl}_{2}, 1 \mathrm{mM}$ DTT and the TG2 amine donor substrate 5-(biotinamido)pentylamine (BAP; $0.05 \mathrm{mM}$ ) at $37{ }^{\circ} \mathrm{C}$ for $30 \mathrm{~min}$. After a short wash with TBS and water, the sections were dried at rt. Then, the sections were fixed with acetone for $10 \mathrm{~min}$ followed by washing with Tris buffered saline (TBS). Sections were blocked with $0.1 \% \mathrm{NaN}_{3}$ and $0.3 \% \mathrm{H}_{2} \mathrm{O}_{2}$ in $\mathrm{TBS}$ for $15 \mathrm{~min}$, washed with TBS (three times $5 \mathrm{~min}$ ) and incubated for $1 \mathrm{~h}$ with horseradish peroxidase avidin-biotin complex. After washing (two times 5 min TBS, then 5 min Tris$\mathrm{HCl}$ ), peroxidase was developed by addition of $\mathrm{DAB}$ and colouring was monitored ad oculos. Nuclear staining using haematoxylin was performed. Sections were washed with Tris- $\mathrm{HCl}$ and water, dehydrated by sequential dipping in ethanol (70, 90, 96, 100 and 100\%) 
and xylene, and mounted with coverslips using Entellan. Microscopy images were obtained using a Leica DN5000B microscope (Leica Microsystems, IL, USA).

\section{Autoradiography}

Autoradiography was performed essentially as described previously [20]. MDA-MB-231 tumour sections $(10 \mu \mathrm{m})$ were washed three times with $50 \mathrm{mM}$ Tris- $\mathrm{HCl}$ buffer $(\mathrm{pH} 7.4)$ for $5 \mathrm{~min}$. Sections were dried under a gentle air flow before incubation for $30 \mathrm{~min}$ with $\left[{ }^{18} \mathrm{~F}\right] 2$ $\left(0.1 \mathrm{MBq} \cdot \mathrm{mL}^{-1}\right)$ in $5 \mathrm{mM}$ Tris- $\mathrm{HCl}, \mathrm{pH} 7.4,5 \mathrm{mM}$ $\mathrm{CaCl}_{2}, 1 \mathrm{mM}$ DTT. As a negative control inhibitor 1 was added to this incubation solution at $100 \mu \mathrm{M}$ (results not shown). Washing was performed using $5 \mathrm{mM}$ Tris- $\mathrm{HCl}$ (three times) followed by dipping in ice cold water. After drying in an air stream, tumour sections were exposed to a phosphorimaging screen (GE Healthcare, Buckinghamshire, UK) for $15 \mathrm{~min}$ and developed on a Typhoon FLA 7000 phosphor imager (GE Healthcare, Buckinghamshire, UK). Visualisation of binding was performed using ImageQuantTL v8.1.0.0 (GE Healthcare, Buckinghamshire, UK).

\section{Statistical analysis}

Where relevant, statistical analysis was performed using either a one-tailed paired Student's $t$ test or a two-tailed paired Student's $t$ test with a confidence interval of $95 \%$.

\section{Results}

mRNA expression of various human transglutaminases in MDA-MB-231 cells and tumour xenograft tissue

The expression of various tumour-related transglutaminases was determined by means of qPCR on both in vitro cultured MDA-MB-231 tumour cells and ex vivo MDAMB-231 tumour material obtained after tumour inoculation in SCID mice. RNA expression levels of transglutaminase types $1-3$ and 5 and blood coagulation factor XIII (TG1, TG2, TG3, TG5 and FXIII) were quantitatively determined relative to GAPDH RNA expression (Fig. 2). In MDA-MB231 tumour cells as well as in tumour tissue, TG2 mRNA was most abundant. Low levels of TG1 mRNA were observed in both cells and tissue, whereas TG3 and TG5 mRNA were absent. FXIII mRNA was absent in cultured MDA-MB-231 tumour cells, whereas in tumour tissue low levels, relative to TG2 mRNA, were found.

\section{Metabolite analysis of $\left[{ }^{11} \mathrm{C}\right] 1$ and $\left[{ }^{18} \mathrm{~F}\right] 2$ in SCID mice}

In SCID mice, compound $\left[{ }^{11} \mathrm{C}\right] \mathbf{1}$ demonstrated moderate metabolism, with $24 \%$ intact tracer after $45 \mathrm{~min}$ (Table 2). Mainly polar metabolites were formed. $\left[{ }^{18} \mathrm{~F}\right] 2$ was fully metabolised to a single metabolite after $45 \mathrm{~min}$. The metabolite was identified by LC-MS/MS analysis as the demethylated parent M1 (Fig. 3).

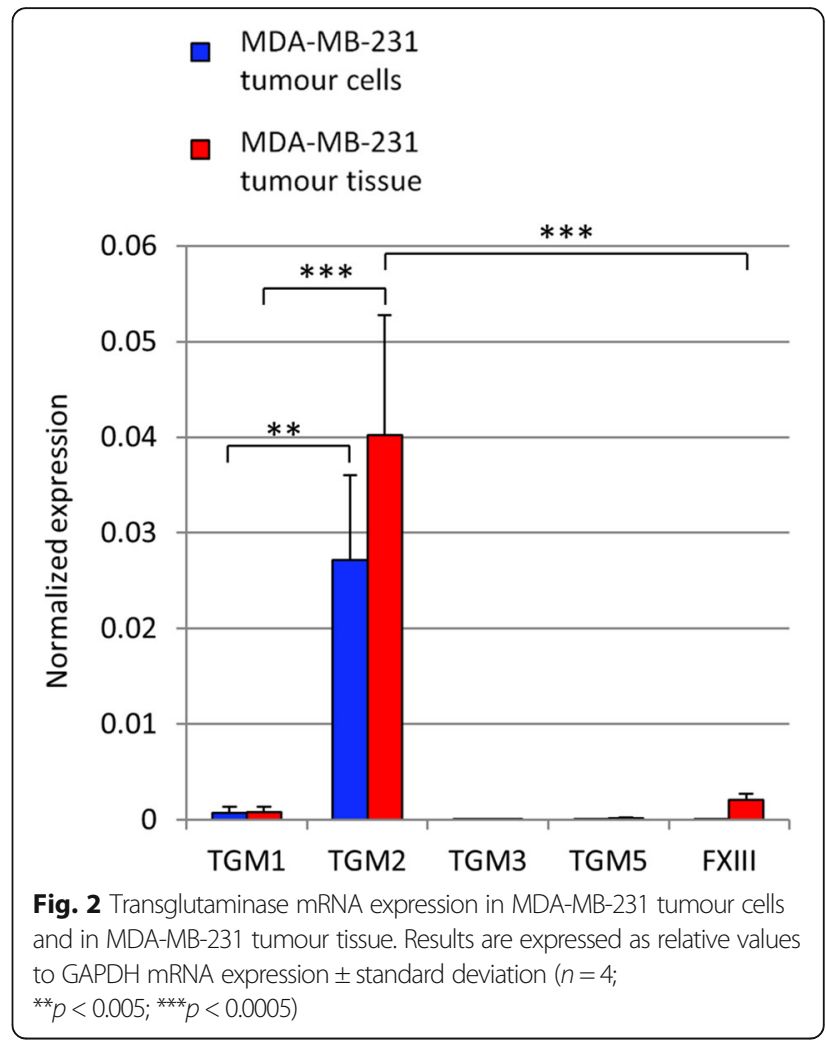

\section{PET scanning}

Representative images $\left(0-30 \mathrm{~min}\right.$ for $\left[{ }^{18} \mathrm{~F}\right] \mathrm{FDG}$ scans and last time-frame, $40-60 \mathrm{~min}$, for $\left[{ }^{11} \mathrm{C}\right] \mathbf{1}$ and $\left.\left[{ }^{18} \mathrm{~F}\right] 2\right)$ and time-activity curves (TAC) of $60 \mathrm{~min}$ scans using $\left[{ }^{11} \mathrm{C}\right] \mathbf{1}$ and $\left[{ }^{18} \mathrm{~F}\right] 2$ under both baseline and blocking conditions ( $n=4$ per group) are depicted in Fig. $4 \mathrm{a}, \mathrm{b}$, respectively. The $\left[{ }^{18} \mathrm{~F}\right] \mathrm{FDG}$ scans revealed rather low uptake in the centres of the tumours, indicating mainly

Table 2 Plasma metabolite profile of $\left[{ }^{11} \mathrm{C}\right] \mathbf{1}$ and $\left[{ }^{18} \mathrm{~F}\right] \mathbf{2}$ following i.v. administration in healthy SCID mice and previously obtained results following i.v. administration in healthy Wistar rats $[19,20]$

\begin{tabular}{llllll}
\hline & $\left.{ }^{11} \mathrm{C}\right] \mathbf{1}$ & & & $\left.{ }^{[8} \mathrm{F}\right] \mathbf{2}$ & \\
\cline { 2 - 3 } & Mouse & Rat & & Mouse & Rat \\
\hline 15 min & & & & \\
Intact (\%) & $56 \pm 14$ & $65 \pm 7$ & & $20 \pm 1$ & $1 \pm 1$ \\
Non-polar (\%) & $24 \pm 15$ & $13 \pm 4$ & $76 \pm 3$ & $98 \pm 1$ \\
Polar (\%) & $20 \pm 5$ & $21 \pm 3$ & $1 \pm 0.2$ & $2 \pm 0$ \\
45 min & & & & \\
Intact (\%) & $24 \pm 1$ & $29 \pm 11$ & $3 \pm 2$ & $0 \pm 0^{*}$ \\
Non-polar (\%) & $28 \pm 8$ & $6 \pm 3$ & $95 \pm 2$ & $92 \pm 3^{*}$ \\
Polar (\%) & $47 \pm 7$ & $65 \pm 12$ & $2 \pm 1$ & $8 \pm 3^{*}$ \\
\hline
\end{tabular}

Following i.v. administration in healthy animals, anaesthetised using isoflurane, blood plasma was obtained at 15 and $45 \mathrm{~min}$. Blood plasma was separated into a polar and non-polar fraction using a SPE method. Non polar fractions were analysed on HPLC. Results are expressed as average percentage of total blood plasma activity \pm standard deviation ( $n=$ at least three per data point). *Animals were sacrificed at 60 min post injection. 

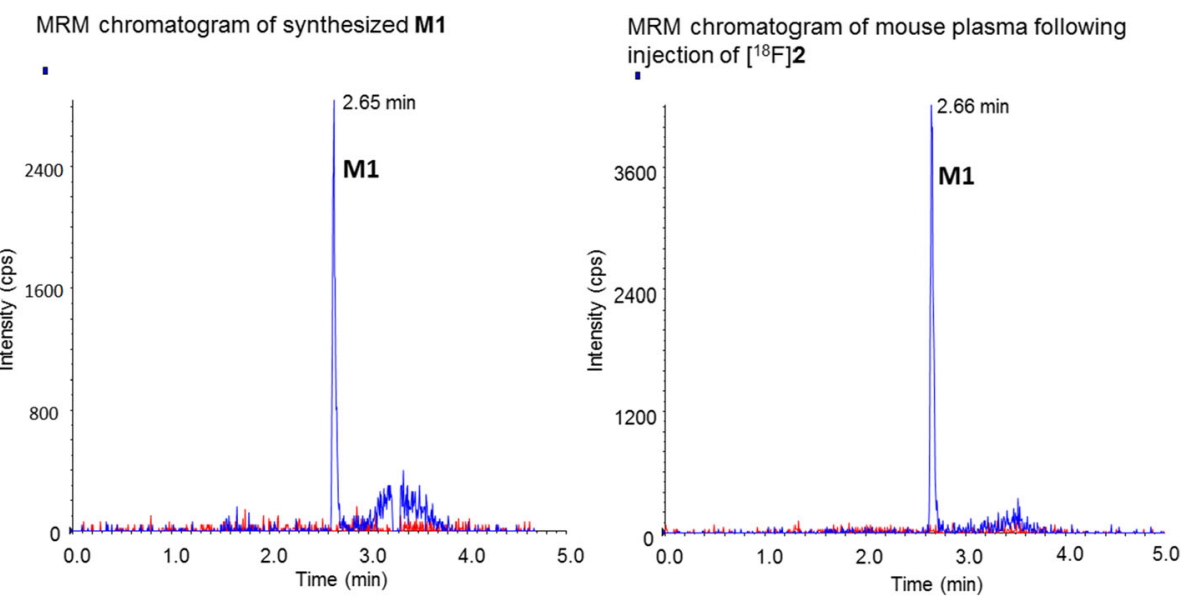

Fig. 3 LC-MS/MS spectra following carrier added administration of $\left[{ }^{18} \mathrm{~F}\right] \mathbf{2}$ to SCID mice. MRM mass transitions 696.2-418.0 m/z (corresponding to 2, red line) and 682.2-626.3 m/z (corresponding to $\mathbf{M 1}$, blue line). Left chromatogram: LC-MS/MS analysis of synthesised $\mathbf{M} 1$. Right chromatogram: LC-MS/MS analysis of mouse plasma after administration of $\left[{ }^{18} \mathrm{~F}\right] \mathbf{2}$. LC-MS/MS analysis indicated full conversion of $\mathbf{2}$ to $\mathbf{M} \mathbf{1}$

that the rims of the tumours were viable. Under baseline conditions, uptake of $\left[{ }^{11} \mathrm{C}\right] \mathbf{1}$ in the tumour at baseline conditions showed a peak at 5-10 min after injection (Fig. 4a). Washout, however, was fast and activity concentrations were comparable to those in background tissue (i.e. the muscle, right femur). Furthermore, blocking of TG2 by pretreatment with ERW1041E did not result in lower tumour activity levels, but rather resulted in a counterintuitive significant increase in tumour activity, as well as in increased muscle activity concentration. PET scanning using compound $\left[{ }^{18} \mathrm{~F}\right] \mathbf{2}$ showed a time-dependent accumulation in tumour tissue up to $1.7 \% \mathrm{ID} / \mathrm{g}$ at the $40-60 \mathrm{~min}$ time-frame, suggesting irreversible tumour targeting. Background values (the muscle, right femur) reached $0.8 \% \mathrm{ID} / \mathrm{g}$ at this time-point, which is significantly lower $(p=0.0004)$ and did not display an increase in tissue activity over the scanning period (Fig. $4 \mathrm{~b}$ ). Pretreatment of the animals with the TG2 inhibitor ERW1041E resulted in a decrease in activity accumulation in the tumour tissue to 1.4 $\% \mathrm{ID} / \mathrm{g}$, although this difference was not statistically significant $(p=0.06)$. A drastic and significant decrease in tumour activity concentration, however, was observed when unlabelled 2 was co-administered, to approximately $1.0 \% \mathrm{ID} / \mathrm{g}(p=0.007)$.

\section{TG2 expression in MDA-MB-231 tumour}

\section{tissue-immunohistochemistry and autoradiography on tumour tissue}

Following sacrifice of the animals, tumour sections were evaluated histochemically for TG2 expression and TG2 activity (representative sections of tumour tissues of three separate animals are shown in Fig. 5). In all tumours, haematoxylin/eosin staining (Fig. 5a) demonstrated areas with low nuclei concentrations in the core of the tumour, hinting at central necrosis. Immunohistochemical staining for TG2 expression (Fig. 5b) resulted in a distribution pattern highly resembling the haematoxylin/eosin staining, showing that TG2 is predominantly expressed in the viable part of the tumours. Transglutaminase-mediated BAP incorporation (Fig. 5c) and in vitro autoradiography employing $\left[{ }^{18} \mathrm{~F}\right] 2$ (Fig. $5 \mathrm{~d}$ ), both means of measuring the open (active) conformation of transglutaminase, demonstrated a similar distribution pattern as observed with the anti-TG2 antibody and the haematoxylin/eosin staining, i.e. incorporation of the substrate and inhibitor in the viable areas of tumour tissue.

\section{Discussion}

Transglutaminase mRNA expression in both MDA-MB231 tumour cells and xenograft tissue essentially was limited to TG2 mRNA and exceeded other transglutaminases by at least a factor ten. The detection of FXIII mRNA in tumour tissue, which is most likely derived from the blood component of the tumour tissue, does not hamper the use of both $\left[{ }^{11} \mathrm{C}\right] \mathbf{1}$ and $\left[{ }^{18} \mathrm{~F}\right] \mathbf{2}$ TG2 PET tracers, as both compounds show no affinity for activated FXIII $[19,20]$. Consequently, these findings imply that the MDA-MB-231 xenograft model is suitable for TG2 PET tracer evaluation.

Previously, metabolic stability of $\left[{ }^{11} \mathrm{C}\right] \mathbf{1}$ as well as $\left[{ }^{18} \mathrm{~F}\right] \mathbf{2}$ was determined ex vivo in blood plasma of healthy Wistar rats. This study, however, was performed in a xenograft model in SCID mice, and therefore, the metabolic stability of both radiotracers was determined again in SCID mice and results were compared with previously obtained rat data $[19,20]$. Metabolism of both $\left[{ }^{11} \mathrm{C}\right] 1$ and $\left[{ }^{18} \mathrm{~F}\right] 2$ in SCID mice highly resembled metabolism of these compounds in Wister rats. Conversion of $\left[{ }^{18} \mathrm{~F}\right] 2$ to the demethylated analogue M1, still a potent TG2 inhibitor, 


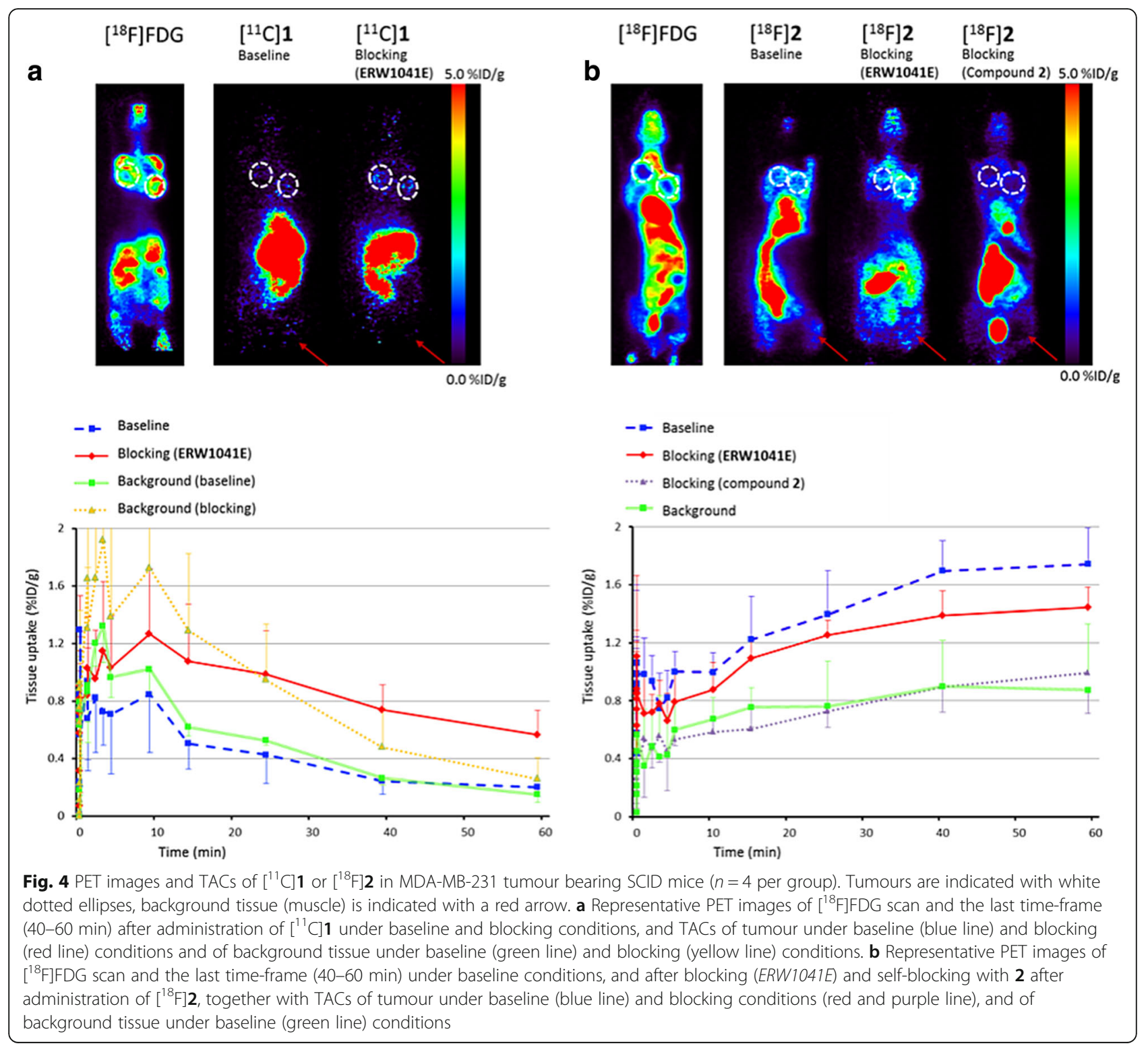

followed the same pattern in both species, although in mice the conversion was less rapid. This difference is likely a result of species-dependent esterase activity [26], and comparable differences between methylester hydrolysis in mice and rats have been reported elsewhere [27]. Importantly, the peptidic backbone and the diazoketone functionality in $\left[{ }^{18} \mathrm{~F}\right] 2$, responsible for selective and irreversible binding, respectively, appear metabolically stable.

To prevent the development of slow-growing and highly necrotic tumours, an orthotopic mouse model was used, in which tumour cells were inoculated in the 2nd thoracic mammary fat pad [21]. At this position minimal interference with surrounding organs such as liver and heart is expected, thus facilitating definition of ROIs and PET data analysis. The use of the structurally unrelated TG2 inhibitor ERW1041E served as a means of determining selectivity of binding of TG2 radiotracers in tumour tissue. ERW1041E was administered at $50 \mathrm{mg} \cdot \mathrm{kg}^{-1}$, as it has been shown that this dose results in inhibition of TG2 activity to background levels in a mouse model of pulmonary hypertension [9]. In addition, the maximum TG2 inhibitory effect was observed $30 \mathrm{~min}$ after ERW1041E administration [9].

Compound $\left[{ }^{11} \mathrm{C}\right] \mathbf{1}$ showed poor tumour uptake and relatively fast washout from the tumour, which was unexpected for an irreversibly binding radiotracer. Therefore, it is believed that the signal is indicative of perfusion rather than TG2 targeting. As both compound 1 and ERW1041E inhibit TG2 by irreversibly binding to the active site cysteine residue, a reduction in tumour uptake would be expected upon blocking with ERW1041E. The fact that both tumour and muscle 


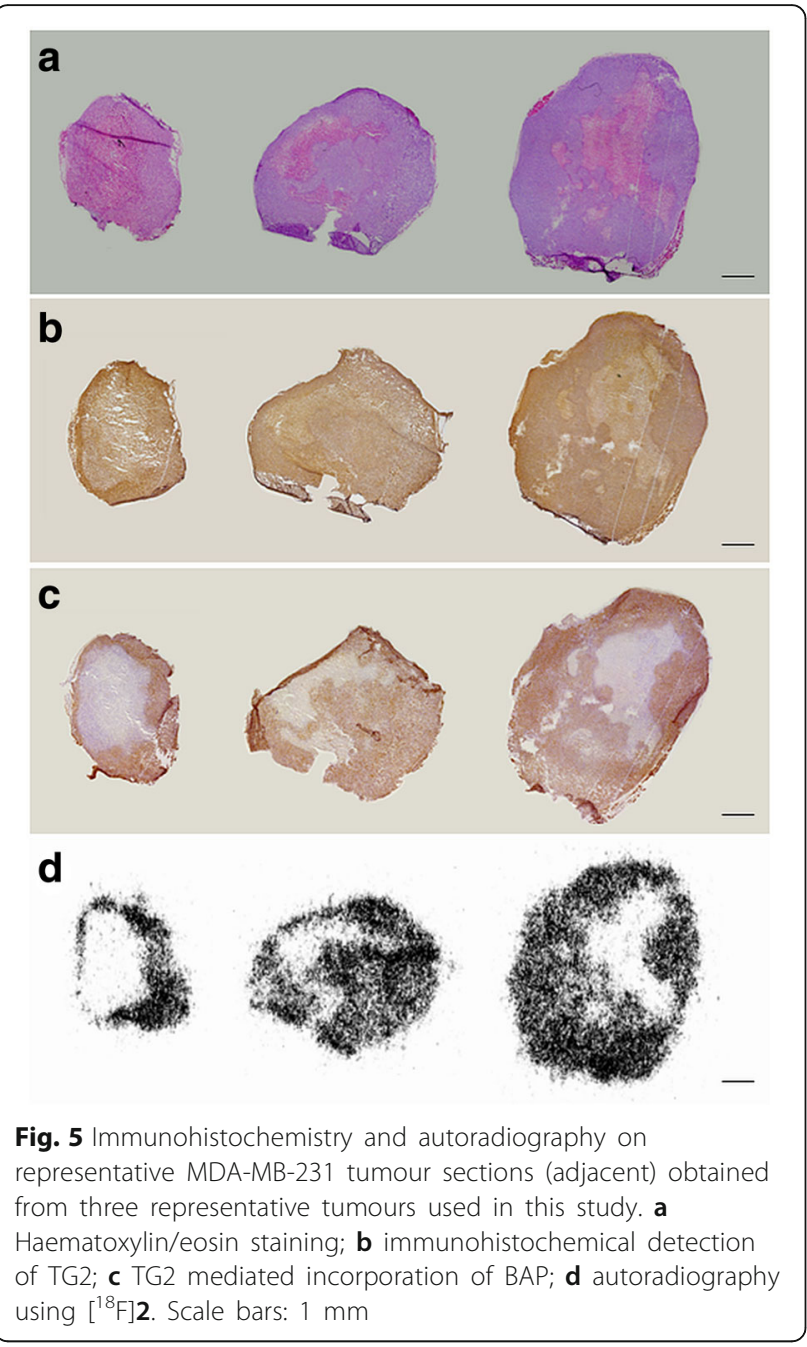

activity concentrations increased as a result of ERW1041E pretreatment suggests to us a decreased clearance of $\left[{ }^{11} \mathrm{C}\right] 1$ or its derived radioactive metabolites from the blood, although no further experiments were performed to support this claim. Despite the promising results that were previously obtained by in vitro autoradiography, where high specific and selective binding of $\left[{ }^{11} \mathrm{C}\right] \mathbf{1}$ to MDA-MD-231 tumour sections was observed [19], $\left[{ }^{11} \mathrm{C}\right] \mathbf{1}$ is not effective as a TG2 PET tracer in vivo. It is unlikely that this apparent ineffectiveness is a result of in vivo metabolism of $\left[{ }^{11} \mathrm{C}\right] \mathbf{1}$ over the time-course of these experiments, as metabolism is moderate. Potentially, large differences between in vitro TG2 inhibitory potency and inhibition in actual biological systems could explain the inability of this compound to image active TG2 in vivo. Different classes of acryl amide based TG2 inhibitors, although highly potent against isolated TG2, have shown a reduction in inhibitory potency in cell or cell lysate assays $[28,29]$. The inhibitory potency of compound $\mathbf{1}$ in similar cell or cell lysate assays is unknown as such experiments have not been described [30].

In contrast to $\left[{ }^{11} \mathrm{C}\right] \mathbf{1},\left[{ }^{18} \mathrm{~F}\right] \mathbf{2}$ displayed higher tumour uptake, which increased over time, indicating irreversible binding of $\left[{ }^{18} \mathrm{~F}\right] 2$ to the tumour tissue. Uptake decreased after pretreating animals with ERW1041E, although the difference was not statistically significant $(p=0.06)$. This seemingly partial inhibition of TG2 might be due to the limited TG2 inhibitory potency of ERW1041E $\left(\mathrm{K}_{\mathrm{i}}: 11 \mu \mathrm{M}\right.$ [23]) compared with compound 2, although previously it has been shown that this compound was able to at least partially inhibit intestinal TG2 in a mouse model [8] and also in a mouse model of pulmonary hypertension to baseline levels [9]. Alternatively, the chosen time-point for pretreatment with ERW1041E (set at $30 \mathrm{~min}$ prior to tracer administration) might not be optimal for full TG2 inhibition, although at this similar time-point a reduction of TG2 activity by a factor of four in a pulmonary hypertension model was observed [9]. The blocking effect when co-administering unlabelled 2 and $\left[{ }^{18} \mathrm{~F}\right] 2 \quad(p=0.007)$, implies that $\left[{ }^{18} \mathrm{~F}\right] 2$ is useful for imaging of local TG2 activity in vivo by indicating specific binding of $\left[{ }^{18} \mathrm{~F}\right] \mathbf{2}$. However, to establish the selectivity of this uptake, more studies are required.

Analysis of tumour sections showed that TG2 was expressed mainly in the more viable rim of the tumours and less in the necrotic core of the tumours. This decreased tumour viability in the core of the tumours is in close accordance with $\left[{ }^{18} \mathrm{~F}\right] \mathrm{FDG}$ findings, which generally displayed higher uptake in the outer tumour areas. Because \% $\mathrm{ID} / \mathrm{g}$ was determined by drawing an area over the full tumour volume, areas inside the tumour that contain no tissue transglutaminase potentially underestimate the actual potential of $\left[{ }^{18} \mathrm{~F}\right] 2$ towards TG2 targeting. As PET images using $\left[{ }^{18} \mathrm{~F}\right] 2$ depicted higher activity concentrations in the outer area of the tumour, for future research, it might prove beneficial to perform such an imaging study at an earlier time-point in tumour development, potentially limiting tumour necrosis and thus increasing signal to noise ratios.

Although previously relatively high tissue transglutaminase expression levels in MDA-MB-231 tumour cell lysates were observed [10], and both TG2 expression and activity were further confirmed in xenografted MDA-MB-231 tumour tissue by means of immunohistochemistry and in vitro autoradiography $[19,20]$, it is unknown to what extent TG2 shows transamidation activity in a biological setting such as the present MDAMB-231 tumour model. Obviously, only in the open TG2 conformation, active site-directed PET tracers can be successfully applied for TG2 imaging $[5,18]$. Therefore, it is expected that primarily extracellular TG2, which is more likely to be in an open conformation due 
to high extracellular calcium concentrations, will be accessible for such tracers [18]. Previous in vitro studies have demonstrated that TG2 is highly expressed on the plasma membrane of MDA-MB-231 tumour cells [31]. Furthermore, pharmacological inhibition of TG2 on MDAMB-231 cells using cell-impermeable small molecule inhibitors or antibodies resulted in decreased cell migration [31, 32] and decreased invasiveness [33], which are both hallmarks of cancer [34]. Based on these findings, it is expected that the accumulation of activity in the tumour using $\left[{ }^{18} \mathrm{~F}\right] 2$ is due to targeting of extracellular TG2. Evidence suggests that extracellular TG2 plays a role in tumour progression by means of its transamidation activity, and therefore, the MDA-MB-231 tumour model appears suitable for evaluation of TG2 PET tracers in vivo, which is supported by the imaging results using $\left[{ }^{18} \mathrm{~F}\right] 2$. Together, the in vivo targeting of TG2 PET tracers is evaluated for the first time and the results suggest that $\left[{ }^{18} \mathrm{~F}\right] 2$ could be used in future research, for example for evaluation of target engagement of other TG2 inhibitors.

\section{Conclusions}

TG2 PET tracers $\left[{ }^{11} \mathrm{C}\right] \mathbf{1}$ and $\left[{ }^{18} \mathrm{~F}\right] \mathbf{2}$ were evaluated in an MB-MDA-231 breast cancer mouse model. Whereas the TG2 targeting potential of $\left[{ }^{11} \mathrm{C}\right] \mathbf{1}$ in this model seemed inadequate, $\left[{ }^{18} \mathrm{~F}\right] 2$ showed signs of TG2 targeting, as tumour activity concentrations were steadily increasing over time and could be blocked with TG2 inhibitors.

\begin{abstract}
Abbreviations
BAP: 5-(Biotinamido)-pentylamine; cDNA: Complementary deoxyribonucleic acid; DAB: 3,3-Diaminobenzidine; DTT: Dithiothreitol; FDG: 2-Fluoro-2-deoxyD-glucose; FXIII: Blood Coagulation Factor XIII; GAPDH: Glyceraldehyde-3phosphate-dehydrogenase; GDP: Guanosine diphosphate; GTP: Guanosine triphosphate; HPLC: High-performance liquid chromatography; LC-MS/ MS: Liquid chromatography-tandem mass spectrometry; MRM: Multiple reaction monitoring; p.i.: Post injection; PBS: Phosphate buffered saline; PET: Positron emission tomography; qPCR: Quantitative polymerase chain reaction; SPE: Solid phase extraction; TBS: Tris buffered saline; TG: Transglutaminase
\end{abstract}

\section{Acknowledgements}

Dr. Carla. F.M. Molthoff, Mariska Verlaan, and Ricardo Vos are kindly acknowledged for their assistance during animal handling and PET scanning sessions. Cyclotron BV Amsterdam is kindly acknowledged for providing carbon-11 and fluorine-18.

\section{Funding}

This research was funded by the AJ Coops Foundation.

\section{Availability of data and materials}

Please contact author for data requests.

\section{Authors' contributions}

BvdW, BD, ADW, MW and RP designed the experiments. BvdW performed the chemical synthesis and radiosynthesis. EK, WB and ADW performed the animal experiments. JJB and JGJMB performed the GPCR and histochemistry experiments. RS performed the LC-MS/MS measurements. All authors analysed the data. BvdW wrote the manuscript. BD, ADW and AL supervised the project. All authors proofread the manuscript. All authors read and approved the final manuscript.
Ethics approval and consent to participate

Not applicable

\section{Competing interests}

R.P. is a shareholder and an employee of Zedira $\mathrm{GmbH}$, a biotech company specialised in transglutaminases.

\section{Publisher's Note}

Springer Nature remains neutral with regard to jurisdictional claims in published maps and institutional affiliations.

\section{Author details}

'Department of Radiology \& Nuclear Medicine, VU University Medical Center, De Boelelaan 1085, 1081 HV Amsterdam, The Netherlands. ${ }^{2}$ Department of Anatomy \& Neurosciences, VU University Medical Center, Amsterdam, The Netherlands. ${ }^{3}$ Zedira GmbH, Darmstadt, Germany.

Received: 28 February 2018 Accepted: 16 April 2018

Published online: 25 May 2018

\section{References}

1. Greenberg CS, Birckbichler PJ, Rice RH. Transglutaminases: multifunctional cross-linking enzymes that stabilize tissues. FASEB J. 1991;5:3071-7.

2. Gundemir S, Colak G, Tucholski J, et al. Transglutaminase 2: a molecular Swiss army knife. Biochim Biophys Acta Mol Cell Res. 1823;2012:406-19.

3. Fesus L, Szondy Z. Transglutaminase 2 in the balance of cell death and survival. FEBS Lett. 2005;579:3297-302.

4. Liu S, Cerione RA, Clardy J. Structural basis for the guanine nucleotidebinding activity of tissue transglutaminase and its regulation of transamidation activity. PNAS. 2002;99:2743-7.

5. Pinkas DM, Strop P, Brunger AT, et al. Transglutaminase 2 undergoes a large conformational change upon activation. PLoS Biol. 2007;5:2788-96.

6. Stamnaes J, Pinkas DM, Fleckenstein B, et al. Redox regulation of transglutaminase 2 activity. J Biol Chem. 2010;285:25402-9.

7. Akimov SS, Krylov D, Fleischman LF, et al. Tissue transglutaminase is an integrinbinding adhesion coreceptor for fibronectin. J Cell Biol. 2000;148:825-38.

8. Dafik L, Albertelli M, Stamnaes J, et al. Activation and inhibition of transglutaminase 2 in mice. PLoS One. 2012;7:e30642.

9. DiRaimondo TR, Klöck C, Warburton $R$, et al. Elevated transglutaminase 2 activity is associated with hypoxia-induced experimental pulmonary hypertension in mice. ACS Chem Biol. 2013;9:266-75.

10. Mehta K, Fok J, Miller FR, et al. Prognostic significance of tissue transglutaminase in drug resistant and metastatic breast cancer. Clin Cancer Res. 2004;10:8068-76.

11. Brown KD. Transglutaminase 2 and NF-KB: an odd couple that shapes breast cancer phenotype. Breast Cancer Res Treat. 2013;137:329-36.

12. Klöck C, DiRaimondo TR, Khosla C. Role of transglutaminase 2 in celiac disease pathogenesis. Semin Immunopathol. 2012;34:513-22.

13. Olsen KC, Sapinoro RE, Kottmann RM, et al. Transglutaminase 2 and its role in pulmonary fibrosis. Am J Respir Crit Care Med. 2011;184:699-707.

14. Johnson TS, Griffin M, Thomas $\mathrm{GL}$, et al. The role of transglutaminase in the rat subtotal nephrectomy model of renal fibrosis. J Clin Invest. 1997;99:2950-60

15. Wilhelmus MMM, van Dam A, Drukarch B. Tissue transglutaminase: a novel pharmacological target in preventing toxic protein aggregation in neurodegenerative diseases. Eur J Pharmacol. 2008;585:464-72.

16. De Laurenzi V, Melino G. Gene disruption of tissue transglutaminase. Mol Cell Biol. 2001;21:148-55.

17. Keillor JW, Apperley KYP, Akbar A. Inhibitors of tissue transglutaminase. Trends Pharmacol Sci. 2015;36:32-40.

18. Van der Wildt B, Lammertsma AA, Drukarch B, et al. Strategies towards in vivo imaging of active transglutaminase type 2 using positron emission tomography. Amino Acids. 2016; https://doi.org/10.1007/s00726-016-2288-y.

19. Van der Wildt B, Wilhelmus MMM, Bijkerk J, et al. Development of carbon-11 labeled acryl amides for selective PET imaging of active tissue transglutaminase. Nucl Med Biol. 2016;43:232-42.

20. Van der Wildt B, Wilhelmus MMM, Kooijman EJM, et al. Development of fluorine-18 labelled peptidic PET tracers for imaging active tissue transglutaminase. Nucl Med Biol. 2017:44:90-104.

21. Price JE, Polyzos A, Zhang RD, et al. Tumorigenicity and metastasis of human breast carcinoma cell lines in nude mice. Cancer Res. 1990;50:717-21. 
22. Ruijter JM, Ramakers C, Hoogaars WM, et al. Amplification efficiency: linking baseline and bias in the analysis of quantitative PCR data. Nucleic Acids Res. 2009;37:e45.

23. Watts RE, Siegel M, Khosla C. Structure-activity relationship analysis of the selective inhibition of transglutaminase 2 by dihydroisoxazoles. J Med Chem. 2006:49:7493-501.

24. Szanda I, Mackewn J, Patay G, et al. National electrical manufacturers association NU-4 performance evaluation of the PET component of the NanoPET/CT preclinical PET/CT scanner. J Nucl Med. 2011;52:1741-7.

25. Nagy $K$, Tóth $M$, Major $P$, et al. Performance evaluation of the small-animal nanoScan PET/MRI system. J Nucl Med. 2013;54:1825-32.

26. Bahar FG, Ohura K, Ogihara T. Species difference of esterase expression and hydrolase activity in plasma. J Pharmacol Sci. 2012;101:3979-88.

27. Slobbe P, Poot AJ, Haumann R, et al. Two anti-angiogenic TKI-PET tracers, $\left[{ }^{11} \mathrm{C}\right]$ axitinib and $\left[{ }^{11} \mathrm{C}\right]$ nintedanib: radiosynthesis, in vivo metabolism and initial biodistribution studies in rodents. Nucl Med Biol. 2016;43:612-24.

28. Prime ME, Andersen OA, Barker JJ, et al. Discovery and structure-activity relationship of potent and selective covalent inhibitors of transglutaminase 2 for Huntington's disease. J Med Chem. 2012;55:1021-46.

29. Badarau E, Wang Z, Rathbone DL, et al. Development of potent and selective tissue transglutaminase inhibitors: their effect on TG2 function and application in pathological conditions. Chem Biol. 2015;22:1347-61.

30. Wityak J, Prime ME, Brookfield FA, et al. SAR development of lysine-based irreversible inhibitors of transglutaminase 2 for Huntington's disease. ACS Med Chem Lett. 2012;3:1024-8.

31. Antonyak MA, Li B, Regan AD, et al. Tissue transglutaminase is an essential participant in the epidermal growth factor-stimulated signaling pathway leading to cancer cell migration and invasion. J Biol Chem. 2009:284:17914-25.

32. Wang $Z$, Griffin M. The role of TG2 in regulating S100A4-mediated mammary tumour cell migration. PLoS One. 2013;8:e57017.

33. Mangala LS, Fok JY, Zorrilla-Calancha IR, et al. Tissue transglutaminase expression promotes cell attachment, invasion and survival in breast cancer cells. Oncogene. 2007;26:2459-70.

34. Hanahan D, Weinberg RA. The hallmarks of cancer. Cell. 2000;100:57-70.

\section{Submit your manuscript to a SpringerOpen ${ }^{\circ}$ journal and benefit from:}

- Convenient online submission

- Rigorous peer review

- Open access: articles freely available online

- High visibility within the field

- Retaining the copyright to your article

Submit your next manuscript at $>$ springeropen.com 